\title{
MEASUREMENT AND EVALUATION OF THE SOCIO-ECONOMIC POTENTIAL OF RURAL AREAS IN POLAND
}

\author{
Agnieszka Sompolska-Rzechula ${ }^{1}, \mathrm{PhD}$; Anna Olenczuk-Paszel ${ }^{2}, \mathrm{PhD}$; Monika Spiewak- \\ Szyjka ${ }^{3}, \mathrm{PhD}$ \\ 1,2,3West Pomeranian University of Technology, Szczecin, Poland
}

\begin{abstract}
The article deals with issues that are socially and economically significant. The aim of the work was to identify, measure and assess the socio-economic potential of rural areas in Poland. The objective was implemented by defining four potentials reflecting the resources of the studied area and the socio-economic potential in general. The empirical part of the study was described using data from the CSO publications Rural areas in Poland in 2016. The study covered the year 2016. The method of the total normalized values of features was used to measure and evaluate the phenomenon creating the linear ordering of rural areas in Poland. The spatial differentiation of the studied phenomenon was observed.
\end{abstract}

Key words: socio-economic potential, rural areas, linear ordering.

JEL code: 010, 015, 018, C38.

\section{Introduction}

According to the nomenclature of the Central Statistical Office (CSO), the territory of Poland is divided into rural and urban areas. The rural areas in Poland include areas of rural municipalities and the rural part of the urban-rural municipalities. In 2016, they occupied over $93 \%$ of the country's area and were inhabited by nearly $40 \%$ of the Polish population (CSO, 2017). Taking into account only the data indicated, it should be confirmed that conducting research on these areas is important from the point of view of the state policy. These areas have resources which proper management can result in their development. The starting point for delineating the path of this development is the measurement and analysis of the potential of the area and constant control of changes in the resources owned.

Bearing in mind the above statements, the main goal of the work was to identify, measure and assess the socio-economic potential of rural areas in Poland.

The main objective was implemented by defining the types of analysed resources (four potentials separated with regard to the substantive criterion and data availability), measuring and assessing the potential of rural areas in the scope of indicated types of potentials and socio-economic potential in general. Data used in the study related to 2016 and are of a secondary nature. They come from the publications of the CSO Rural areas in Poland in 2016. The study conducted a linear ordering of rural areas in Polish voivodeships using the total standardized values of features. Spatial diversification of the socio-economic potential of rural areas was observed, which is confirmed by differences in positions occupied by rural areas of voivodeships in the presented rankings.

\section{Socio-economic potential}

The socio-economic potential is a complex concept referring to the resources of specific areas determining their development, which in literature is understood as ", long and complex process of positive quantitative and qualitative changes thanks to which the existing phenomena are being improved, and new ones are emerging and developing in the sphere of all economic, cultural and social activities and socio-production and political-systemic relations" (Kupiec L., 2008).

Rural areas in Poland have a huge, still insufficiently used, endogenous social and economic potential (Potential of rural areas ..., 2011). However, scientific research has confirmed their dynamic

\footnotetext{
${ }^{1}$ Agnieszka.sompolska-rzechula@zut.edu.pl

2 Anna.olenczuk-paszel@zut.edu.pl

3 Monika.spiewak-szyjka@zut.edu.pl
} 
development in recent years (Wojewodzka-Wiewiorska A., Dudek H., 2016). These areas experienced a great civilization progress, expressed in the improvement of the quality of life, equipment of technical and social infrastructure, or the degree of spatial development. A part of rural areas has lost the typically rural character and has become similar to urban areas (Action plan for ..., 2015).

The socio-demographic resources constituting the population resource, which consists of the number of inhabitants, population density, population structure by sex and age, fertility, mortality and migration are an important component of the socio-economic potential. The unemployment rate, the employment rate, the number of employed and registered business entities are equally important. In recent years, the number of divorces in Poland has increased, as well as the age of women deciding on the birth of their first child, thus leading to the decline in the number of births and the increase in the number of extramarital births, which indicates their similarity with the urban areas. The analysis of demographic potential indicates a relatively favourable age structure of the rural population. In rural areas there was a higher percentage of population in pre-working age than in cities and a lower share of population in post-productive age. As a result of changes in economic age groups that took place in recent years, consisting in an increase in the number of people in the productive age and a decline in the number of people in the pre-working age, the demographic load factor decreased in the countryside. In 2016, there were 59 people in non-productive age per 100 inhabitants of rural areas in working age, compared to 64 in cities (CSO, 2017).

The socio-demographic potential is associated with social infrastructure, which include educational, cultural and health institutions. Their activity determines the quality of sociodemographic potential and determines the quality of life of the population. An important indicator for rural areas is the level of education of the population and access to various forms of education (Cintina V., Pukite V., 2018). In the Polish countryside, the availability of pre-school education is lower than in cities. In the school year 2016/2017, the number of children aged 3-6 under care in the pre-school education institutions amounted to 634 per 100 children and doubled compared to the school year 2006/2007. The rural areas of Poland are also rich in objects of national heritage and cultural institutions. However, the rural population, due to the more difficult financial situation compared to the urban population, is less involved in cultural activities. In the field of social infrastructure of rural areas in Poland, an increase in access to out-patient health care services (clinics and medical practices) was also noted. In comparison to 2006, an increase in the number of these units was observed (by $36.4 \%$ ) and the number of advice provided in them (by $11.3 \%$ ) (CSO, 2017).

Oher important factors determining the socio-economic potential of rural areas in Poland are housing conditions and equipping the areas with technical infrastructure. The importance of housing results from the role of housing as a basic good and at the same time satisfying a number of higherorder needs. Housing is essential for the standard of living of citizens, as well as for the strength and economic development of the country (Nykiel L., 2012). Housing resources in rural areas in 2016 accounted to $32.6 \%$ of housing resources in Poland. The average usable area of the apartment located in the rural areas was greater than in cities (93.12 $\mathrm{m}^{2}$ compared to $64,45 \mathrm{~m}^{2}$ ). However, taking into account the fact that the number of people in this area per one apartment in the village was higher than in cities, there is a similar usable area of an apartment per one person as in cities (CSO, 2017).

Technical infrastructure is a key factor in shaping the settlement network. It determines the attractiveness of rural areas as a place to invest and live and directly affects the process of creating 
new jobs, and improves the standard of living and encourages migration to the countryside, hampering the depopulation of rural areas (Potential of rural areas ..., 2011). Although disproportions in equipping apartments with installations between cities and villages have decreased, still the apartments in the village were equipped worse than apartments in the cities. Still a significant percentage of apartments inhabited in rural areas was connected to local devices, used gas from cylinders ( $73.6 \%$ compared to $18.7 \%$ in cities) and was heated with furnaces ( $16.0 \%$ compared to $13.0 \%$ in cities) (CSO, 2017).

The advantage of rural areas in Poland is their natural diversity. The activities in the field of environmental protection are important for social and economic development. They may take the form of rational shaping and management of its resources in accordance with the principle of sustainable development, preventing pollution, recycling or maintaining and restoring natural elements to the proper state (Sompolska-Rzechula A., Olenczuk-Paszel A., 2017). In recent years, in rural areas, there has been a significant increase in the number of publicly available facilities and areas (including parks and green areas), typical of urban areas. There is a decrease in emissions of dust and gas pollution, with a simultaneous increase in the amount of municipal waste generated by household in rural areas (CSO, 2017).

Socio-economic potential of rural areas in Poland is diverse, which is the cause of various development problems. The peripheral rural municipalities are in the worst situation, which are far from a large urban centre and the strength of its impact. Development policy must be targeted and correspond to the real problems of a given areas, and at the same time it must be based on local values and strengths. This is done by research covering the resources of those areas in which they are identified, measured and evaluated.

\section{Method}

The socio-economic potential of rural areas is identified with resources of a different nature existing in a given area, at a specific point in time and described by means of indicators reflecting their essence. It is a complex phenomenon, for the measurement and assessment of which the methods should be used which enable the comparison of objects described by a set of many features by reducing them to a synthetic measure, being a function that aggregates partial information contained in individual characteristics (Gatnar E., Walesiak M., 2004). The synthetic variable is obtained by implementing the following stages (Grabinski T., 1992, Wysocki F., 2010): determining the initial matrix of characteristics, reducing the matrix of diagnostic features, determining the direction of character preferences, giving weight to features, normalizing features, aggregation of standardized features, creating a linear ordering of objects due to level of the complex phenomenon under consideration. Among many methods based on synthetic variables, the method of total normalized variables was selected for the study. The normalization was performed with the help of zero unitarization (Kukula K., 2000) for stimulants, whereas destimulants were changed into stimulants according to the differential transformation (Panek T., 2009). The value of the synthetic variable was calculated using the arithmetic mean:

$$
s_{i}=\frac{1}{m} \sum_{j=1}^{m} z_{i j} ; i=1, \ldots, n
$$

where: $m$ - number of diagnostic features, $n$ - number of objects, $z_{i j}$ - normalized value of diagnostic features. The higher the value of the meter $s_{i}$, the higher the level of development of a given object in terms of a given criterion. 


\section{Research results and discussion}

Bearing in mind the purpose of the work, which concerns the measurement and assessment of the socio-economic potential of rural areas in Poland and the availability of data, in the work, taking into account the substantive criterion, the following initial list of diagnostic features included in the four potential groups was adopted:

I. Socio-demographic:

$X_{1}$ - working age population in \% of the total population; $X_{2}$ - marriages per 1000 of population; $X_{3}$ - alive births per 1000 of population; $X_{4}$ - natural increase per 1000 of population; $X_{5}$ - total fertility rate; $X_{6}$ - demographic dynamics coefficient; $X_{7}$ - deaths per 1000 of population; $X_{8}$ - balance of internal and foreign migration per permanent residence per 1000 of population; $X_{9}$ - professional activity rate $(\%) ; X_{10}$ - employment rate $(\%) ; X_{11}$ - unemployment rate $(\%) ; X_{12}$ - working per 1000 of inhabitants; $X_{13}$ - entities of the national economy newly registered in the REGON register per 1000 of population.

II. Social infrastructure:

$X_{1}$ - children in pre-school education institutions aged 3-6 per 1000 of children aged $3-6 ; X_{2}-$ number of students per 1 primary school; $x_{3}$ - gross enlargement ratio in primary schools; $x_{4}-$ borrowing the book collection from public libraries per 1 reader in volumes; $X_{5}$ - public libraries per 1000 of population; $X_{6}$ - cultural institutions per 1000 of population; $X_{7}$ - population per 1 object of outpatient health care; $X 8$ - population per 1 generally accessible pharmacy and pharmacy point; $X_{9}$ - advice per 1 inhabitant; $X_{10}$ - houses and social welfare facilities per 1000 of population; $X_{11}$ accommodation per 1000 of population; $X_{12}$ - sports clubs per 1000 of population.

III. Housing and technical infrastructure:

$X_{1}$ - apartments per 1000 of population; $X_{2}$ - apartments equipped with water supply in $\%$ of total housing; $X_{3}$ - apartments equipped with a lavatory in \% of total housing; $X_{4}$ - apartments equipped with a toilet in \% of total housing; $X_{5}$ - apartments equipped with gas from the network in $\%$ of total housing; $x_{6}$ - apartments equipped with central heating in $\%$ of total housing; $x_{7}-$ apartments put into use per 1000 of population; $X_{8}$ - water supply network in $\mathrm{km} / 100 \mathrm{~km}^{2} ; X_{9}-$ sewage network in $\mathrm{km} / 100 \mathrm{~km}^{2} ; X_{10}$ - gas network in $\mathrm{km} / 100 \mathrm{~km}^{2} ; X_{11}$ - population using the water supply network in $\mathrm{w} \%$ of total population; $X_{12}$ - population using the sewerage network in $\%$ of total population; $X_{13}$ - population using the gas network in $\%$ total population; $X_{14}$ - public outdoor roads with hard improved surface in $\mathrm{km} / 100 \mathrm{~km}^{2}$.

IV. Environmental:

$X_{1}$ - woodiness $\% ; X_{2}$ - walking and recreation parks, green areas and greenery areas per 1 inhabitant in $\mathrm{m}^{2} ; x_{3}$ - industrial and municipal sewage treated in $\%$ of wastewater requiring treatment; $X_{4}$ - sewage treated per $100 \mathrm{~km}^{2}$ in dam ${ }^{3}$ (municipal); $X_{5}$ - population using the sewage treatment plants in $\%$ of total population; $x_{6}$ - waste (excluding municipal waste) generated per 1 $\mathrm{km}^{2}$ in $\mathrm{t} ; X_{7}$ - collected municipal waste mixed per 1 inhabitant in $\mathrm{kg}$.

The method of linear ordering of objects based on the total normalized values of diagnostic features was used to implement the goal. The proceedings used the zero uniformization method (Kukuła K., 2000). Previously, the type of features was determined and the following was assumed as destimulants: the unemployment rate ( \%) and collected municipal waste mixed per 1 inhabitant in $\mathrm{kg}$, which were transformed into stimulants.

The selection of diagnostic features for the study proceeded according to the following stages:

1) Determining the degree of variability of features using the coefficient of variation. 
Assessment of the degree of correlating features in particular areas using the Hellwig parametric method.

2) Selection of features from individual areas.

3) Applying the substantive approach, recognizing that all areas are equally important from the point of view of the socio-economic potential of the areas studied, three features from each area were selected.

Finally, the following set of diagnostic features was obtained relating to the potential:

I. Socio-demographic: $X_{4}, X_{8}, X_{11}$.

II. Social infrastructure: $X_{5}, X_{6}, X_{9}$.

III. Housing and technical infrastructure: $X_{7}, X_{8}, X_{12}$.

IV. Environmental: $X_{1}, X_{4}, X_{7}$.

The general potential of socio-economic rural areas in Poland was determined by means of all the features that make up particular types of potentials.

Table 1 presents the results of linear ordering of rural areas in Poland, taking into account particular types of potentials and socio-economic potential in general.

Table 1

\section{Linear ordering of rural areas in Poland, taking into account particular types of potentials and socio-economic potential in general}

\begin{tabular}{|c|c|c|c|c|c|}
\hline \multirow[b]{2}{*}{ Voivodeship } & \multicolumn{5}{|c|}{ The place in the ranking in terms of potential } \\
\hline & 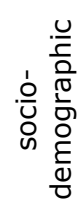 & 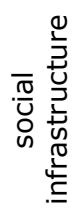 & 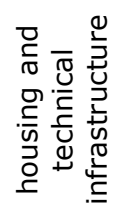 & 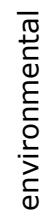 & $\begin{array}{l}\bar{\sigma} \\
\frac{\pi}{d} \\
\frac{\mathbb{d}}{\sigma} \\
\sigma \\
. \subseteq\end{array}$ \\
\hline dolnoslaskie & 3 & 4 & 6 & 12 & 4 \\
\hline kujawsko-pomorskie & 8 & 10 & 4 & 16 & 8 \\
\hline lubelskie & 13 & 6 & 15 & 7 & 15 \\
\hline lubuskie & 9 & 13 & 14 & 6 & 13 \\
\hline lodzkie & 7 & 8 & 10 & 13 & 10 \\
\hline malopolskie & 4 & 9 & 5 & 3 & 3 \\
\hline mazowieckie & 6 & 15 & 7 & 9 & 9 \\
\hline opolskie & 10 & 1 & 13 & 10 & 7 \\
\hline podkarpackie & 14 & 3 & 8 & 1 & 6 \\
\hline podlaskie & 11 & 7 & 16 & 8 & 14 \\
\hline pomorskie & 2 & 11 & 1 & 5 & 2 \\
\hline slaskie & 5 & 5 & 3 & 2 & 1 \\
\hline swietokrzyskie & 15 & 12 & 9 & 4 & 12 \\
\hline warminsko-mazurskie & 16 & 14 & 12 & 11 & 16 \\
\hline wielkopolskie & 1 & 16 & 2 & 14 & 5 \\
\hline zachodniopomorskie & 12 & 2 & 11 & 15 & 11 \\
\hline
\end{tabular}

Source: authors' calculation based on Rural areas in Poland in 2016, CSO, Warszawa, 2017

The rural areas of the wielkopolskie voivodeship occupy the first place in the ranking in terms of socio-demographic potential. This is due to the lowest value of the $X_{11}$ feature - the unemployment rate ( $\%$ ) which is the destimulant and from the high values of variables constituting stimulants. The lowest value of the measure, and thus the last place in the ordering goes to rural areas of the warminsko-mazurskie voivodeship, which are characterized by values of features unfavourable from the point of view of the socio-demographic potential. 
In terms of the potential for social infrastructure, the opolskie voivodship took the highest place. This situation results from the highest value of the $X_{5}$ feature - public libraries per 1000 of population and high values of the $X_{6}$ features - cultural institutions per 1000 of population and $X_{9}$ - advice per 1 inhabitant. The last place in the linear ordering of rural areas in terms of social infrastructure is taken by the wielopolskie voivodeship. The values of the features adopted in the study are unfavourable in this case.

The pomorskie voivodeship occupies the first position in the ranking of rural areas regarding the housing potential and technical infrastructure. In this area, the highest values of the following features were recorded: $X_{7}$ - apartments put into use per 1000 of population and $X_{12}$ - population using the sewerage network in $\%$ of total population. The rural areas of the podlaskie voivodeship rank last in the ranking, which results from the values achieved by the characteristics adopted in the study, unfavourable for the described potential.

High values of the characteristics of stimulants $\left(X_{1}\right.$ - woodiness $\%, X_{4}-$ sewage treated at 100 $\mathrm{km}^{2}$ in dam $^{3}$ (municipal)) and low value of the destimulant feature $\left(X_{7}\right.$ - collected municipal waste mixed per 1 inhabitant in $\mathrm{kg}$ ) determined the first place in rural areas of the podkarpackie voivodeship in the ranking of these areas in terms of environmental potential. In 2016, the worst position, taking into account the accepted diagnostic features, was taken by the kujawsko-pomorskie voivodeship, which was characterized by the low forest cover $(\%)$, low value of the characteristic for sewage treated at $100 \mathrm{~km}^{2}$ in dam ${ }^{3}$ (municipal) and high value of the feature related to collected municipal waste mixed per 1 inhabitant in $\mathrm{kg}$.

The ordering if rural areas of Poland in terms of the socio-economic potential in general was done as the line linear ordering. To build this ranking, the diagnostic features taken into account in individual potentials were used. The leading position is occupied slaskie voivodeship, which ranks high in particular rankings (from the $2^{\text {nd }}$ place due to the environmental potential to the $5^{\text {th }}$ place due to the socio-demographic potential and technical infrastructure). This is a consequence of the favourable values of the characteristics accepted for the study. The ranking of rural areas due to the socio-economic potential in general is closed by the warminsko-mazurskie voivodeship, which in separate areas of analysis was located at distant places of rankings (from the 11 place in the field of environmental potential to the $16^{\text {th }}$ place in the socio-demographic potential).

The analysis of data on the position of rural areas in individual voivodeships made with reference to four separate potentials is the basis for stating that these areas are ranked on various positions of the rankings. In 2016, the same position was recorded only in relation to two voivodeships. The slaskie voivodeship occupies the fifth position in terms of the ranking on socio-economic potential and social infrastructure, while the opolskie voivodeship is tenth in terms of the socio-economic and environmental potential. The biggest difference in the occupied places concerns the wielkopolskie voivodeship, which in the case of socio-economic potential took the $1^{\text {st }}$ place, and in the case of social infrastructure the $16^{\text {th }}$ place. The difference between the $1^{\text {st }}$ and $14^{\text {th }}$ place concerned the podkarpackie voivodeship, respectively, in terms of environmental and socio-demographic potential, while the difference in the position of the zachodniopomorskie voivodeship from the $2^{\text {nd }}$ place in the area of social infrastructure to $15^{\text {th }}$ in terms of environmental potential.

In the case of eleven voivodeships, it was observed that their positions in the ranking in terms of socio-economic potential in general were the same as positions in one of the rankings created for four partial potentials, e.g. in the ranking in terms of socio-economic potential in general terms and 
the socio-demographic potential, the second place is occupied by the rural areas of the pomorskie voivodeship, whereas the sixteenth by the rural areas of the warminsko-mazurskie voivodeship.

It was analysed whether there are links between voivodeships' positions in terms of particular types of potential and potential in general terms. Connections were observed in two cases - between the positions due to socio-demographic and residential potential as well as technical infrastructure and items according to the general potential. This is evidenced by the Kendall correlation coefficient $\tau$, respectively: 0.550 and 0.667 , according to which the higher the position of the voivodeship in terms of socio-demographic or housing potential and technical infrastructure, the higher the position in terms of socio-economic potential. In other cases, the Kendall correlation coefficient $\tau$ values were low, indicating a lack of dependence between the positions of the voivodeship in individual orders, e.g. the podlaskie voivodeship occupied the seventh place in the ranking due to the potential of social infrastructure and at the same time the sixteenth place considering the housing potential and technical infrastructure.

\section{Conclusions}

The conducted study allowed to draw the following conclusions:

1) The assessment of the socio-economic potential of rural areas, which is a complex issue, has been made due to the identification of resources available to these areas.

2) All features accepted in the study were characterized by strong variability, thanks to which they could effectively discriminate against the rural areas.

3) Rural areas in Poland were strongly spatially diverse in terms of socio-economic potential and partial potentials, taking into account the adopted diagnostic features, which was confirmed by the analysis using the selected method of linear ordering.

4) In the rankings of rural areas created taking into account socio-demographic potential, social infrastructure, housing conditions and technical and environmental infrastructure, the areas of the wielkopolskie, oplskie, pomorskie and podkarpackie voiwodeship took the first place, respectively. The last place in the ordering was given to the areas of warminsko-mazurskie, wielkopolskie, podlaskie and kujawsko-pomorskie voivodeschip.

5) The leading place in the linear ordering of the examined areas in terms of socio-economic potential in general was taken by the slaskie voivodeship and the last by the warminskomazurskie.

6) There were reports of connections between voivodeships' positions due to socio-demographic and housing potential, as well as technical infrastructure and items according to socio-economic potential in general. This is confirmed by the high Kendall correlation coefficient $\tau$ value. In the case of other orders, there was a lack of compliance in the positions occupied.

\section{Bibliography}

1. Cintina, V., Pukite, V. (2018). Analysis of Influencing Factors of Use of Agricultural Land, Research for Rural Development 2018. Vol. 1, Jelgava, Latvia: Latvia University of Agriculture, pp. $181-182$.

2. Gatnar, E., Walesiak, M. (red.). (2004). Metody statystycznej analizy wielowymiarowej w badaniach marketingowych (Methods of statistical multidimensional analysis in marketing research). Wydawnictwo Akademii Ekonomicznej we Wroclawiu, Wroclaw, p. 351.

3. Grabinski, T. (1992). Metody taksonometrii (Methods of taxononometry). Wydawnictwo Akademii Ekonomicznej w Krakowie, Krakow, p. 136-137.

4. Kukula, K. (2000). Metoda unitaryzacji zerowanej (The method of zero-standardization). Wydawnictwo Naukowe PWN, Warszawa, p. 79. 
5. Kupiec, L. (2008). Jaki rozwoj? (What development?), Rozwoj regionalny a rozwoj zrownowazony. (Regional development and sustainable development), A.F. Bocian (red.). Wydawnictwo Uniwersytetu w Bialymstoku, Bialystok, p. 22

6. Nykiel, L. (2012). Mieszkania na wynajem jako warunek rozwoju rynku mieszkaniowego (Flats for rent as a condition for the development of the housing market). Studia i Materialy Towarzystwa Naukowego Nieruchomosci - vol. $20 \mathrm{nr} 3$, p. 95.

7. Obszary wiejskie w Polsce w 2016 r. (Rural areas in Poland in 2016). (2017). GUS (CSO), Warszawa, pp. 21-23.

8. Panek, T. (2009). Statystyczne metody wielowymiarowej analizy porownawczej (Statistical methods of multivariate comparative analysis). Wydawnictwo Szkoly Glownej Handlowej w Warszawie, Warszawa, p. 67.

9. Plan dzialania dla obszarow wiejskich (Action plan for rural areas). (2015). Kancelaria Prezydenta RP, Warszawa, pp. 9-10.

10. Potencjal obszarow wiejskich szansa rozwoju (Potential of rural areas as a chance for development). (2011). Kancelaria Prezydenta RP, Spala, p. 27.

11.Sompolska-Rzechula, Olenczuk-Paszel, (2017). Poziom zycia ludnosci na obszarach wiejskich i miejskich w Polsce, (Level of living of the population on rural and urban areas in Poland), Wies i Rolnictwo, IRWiR PAN, Warszawa, pp. 83-84.

12. Wojewodzka-Wiewiorska, A., Dudek, H. (2016). Dynamics of Rural Areas Development in Poland Convergence Analysis, Research for Rural Development 2016. Vol. 2, Jelgava, Latvia: Latvia University of Agriculture, pp. $99-105$.

13. Wysocki, F. (2010). Metody taksonomiczne $w$ rozpoznawaniu typow ekonomicznych rolnictwa i obszarow wiejskich (Taxonomic methods in recognizing economic types of agriculture and rural areas). Wydawnictwo Uniwersytetu Przyrodniczego w Poznaniu, Poznan, p. 143-145. 